\title{
Gas Production and Rumen Fermentation Characteristics of Buffalo Diets Containing By-Product from Some Sorghum Varieties
}

\author{
Sugoro $\mathrm{I}^{1}$, Wiryawan $\mathrm{KG}^{2}$, Astuti $\mathrm{DA}^{2}$, Wahyono $\mathrm{T}^{1}$ \\ ${ }^{I}$ Field of Agriculture, Center for Application of Isotope and Radiation, National Nuclear Energy Agency of Indonesia \\ ${ }^{2}$ Department of Nutrition Science dan Feed Technology, Faculty of Animal Science, Bogor Agricultural University \\ E-mail: irawansugoro@gmail.com
}

(received 21-09-2015; revised 12-11-2015; accepted 26-11-2015)

\begin{abstract}
ABSTRAK
Sugoro I, Wiryawan KG, Astuti DA, Wahyono T. 2015. Karakteristik produksi gas dan fermentasi rumen pada ransum kerbau yang mengandung hasil samping dari beberapa varietas tanaman sorgum. Indones J Anim Vet Sci. 20(4): 242-249. DOI: http://dx.doi.org/10.14334/jitv.v20i4.1241

Sumber serat yang berasal dari sorgum adalah salah satu bahan pakan potensial untuk kerbau. Sorgum Samurai 1 dan Samurai 2 merupakan varietas sorgum yang berasal dari pemuliaan mutasi radiasi indukan sorgum varietas Pahat. Tujuan dari penelitian ini adalah untuk membandingkan secara in vitro ransum kerbau yang mengandung 50\% sumber serat dari jerami sorgum Samurai 2 atau bagas sorgum Samurai 1 dibandingkan dengan ransum yang mengandung 50\% jerami sorgum Pahat. Penelitian ini menggunakan Rancangan Acak Lengkap enam perlakuan dengan tiga ulangan. Pengambilan cairan rumen kerbau dalam waktu yang berbeda berperan sebagai ulangan. Enam pakan perlakuan terdiri dari P1 (50\% jerami sorgum Pahat $+50 \%$ konsentrat), P2 (50\% silase jerami sorgum Pahat $+50 \%$ konsentrat), P3 (50\% jerami sorgum Samurai $2+50 \%$ konsentrat), P4 (50\% silase jerami sorgum Samurai $2+50 \%$ konsentrat), P5 (50\% bagas sorgum Samurai $1+50 \%$ konsentrat) dan P6 (50\% silase bagas sorgum Samurai $1+50 \%$ konsentrat). Sebanyak $200 \mathrm{mg}$ bahan kering (BK) ransum diinkubasi dalam $30 \mathrm{ml}$ medium cairan rumen-buffer selama 48 jam. Peubah yang diamati adalah produksi gas total, konsentrasi CH4 dan karakteristik fermentasi rumen. Hasil penelitian menunjukkan bahwa $\mathrm{P} 2$ dan $\mathrm{P} 4$ menghasilkan produksi gas tertinggi $(\mathrm{P}<0,05)$ berturut-turut 60,99 dan 60,86 ml/200 mg BK. Perlakuan P1, P2 dan P4 menghasilkan konsentrasi $\mathrm{CH} 4$ terendah $(\mathrm{P}<0,05)$ dengan nilai berturut-turut 10,57; 10,90; dan 9,82\% dari total gas. Perlakuan P4 menghasilkan VFA total, degradasi Bahan Kering (BK) dan degradasi Bahan Organik (BO) dengan nilai berturut-turut 109,83 mM; 62,93; dan 59,97\%. Konsentrasi amonia (NH3) tidak berbeda nyata antar perlakuan. Kesimpulan dari penelitian ini adalah sumber serat silase jerami sorgum Samurai 2 lebih baik dibandingkan jerami sorgum Pahat dan bagas sorgum Samurai 1 dalam ransum kerbau.
\end{abstract}

Kata Kunci: Fermentasi Rumen, Konsentrasi CH4, Kerbau, Sorgum

ABSTRACT

Sugoro I, Wiryawan KG, Astuti DA, Wahyono T. 2015. Gas production and rumen fermentation characteristics of buffalo diets containing by-product from some sorghum varieties. Idones J Anim Vet Sci. 20(4): 242-249. DOI: http://dx.doi.org/10.14334/jitv.v20i4.1241

Sorghum is one of potencial fibre sources as buffalo feed. Quality of sorghum could be increased by irradiation mutation breeding. Samurai 1 and Samurai 2 were products of the irradiation mutation breeding of Pahat. This study was conducted to compare buffalo diets containing Samurai 2 sorghum straw and Samurai 1 bagasse sorghum compared with Pahat sorghum straw using in vitro study. Completely randomized design with 6 treatments and 3 replications was applied in this experiment. The treatment diets were P1 (50\% Pahat sorghum straw $+50 \%$ concentrate), P2 (50\% Pahat sorghum straw silage $+50 \%$ concentrate), P3 (50\% Samurai 2 sorghum straw $+50 \%$ concentrate), P4 (50\% Samurai 2 sorghum straw silage $+50 \%$ concentrate), P5 (50\% Samurai 1 sorghum bagasse $+50 \%$ concentrate) and P6 (50\% Samurai 1 sorghum bagasse silage $+50 \%$ concentrate). The $200 \mathrm{mg}$ DM samples of diets were incubated in $30 \mathrm{ml}$ rumen-buffer fluid for 48 hours. Variables measured were total gas production, $\mathrm{CH} 4$ production and rumen fermentation characteristics. Results showed that $\mathrm{P} 2$ and $\mathrm{P} 4$ produce the highest of gas production $(\mathrm{P}<0.05)$ with 60.99 and $60.86 \mathrm{ml} / 200 \mathrm{mg}$ dry matter respectively. Treatments of P1, P2 and P4 produced the lowest $\mathrm{CH} 4$ concentration $(\mathrm{P}<0.05)$ with $10.57,10.90$ and $9.82 \%$ of total gas, respectively. The $\mathrm{P} 4$ produced the highest total volatile fatty acids (VFA), dry matter degradability and organic matter degradability with $109.83 \mathrm{mM}, 62.93 \%$ and $59.97 \%$ respectively, meanwhile ammonia (NH3) concentration was not significantly different. The conclusion showed that straw silage of Samurai 2 was comparable to the Pahat sorghum straw and Samurai 1 bagasse sorghum as buffalo diet.

Key Words: Buffalo, CH4 Concentration, Rumen Fermentation Characteristics, Sorghum

\section{INTRODUCTION}

Utilization of sorghum for forage will strongly support livestock management in marginal area.
Sorghum is a multifunctional crop producing food, feed, bioethanol and another industrial material (Sirappa 2003). As a fibre sources, sorghum may be fed in form of fresh straw or silage. Silage processing was 
aimed for preservation and nutrients retaining (Colombo et al. 2007). Combined sorghum straw and concentrate diet had equal quality and may replace combined corn straw and concentrate diet. Fibre of sorghum crop may be also obtained from sorghum bagasse, which is a processing waste of bioethanol made of sorghum. Combined baggase and concentrate $(50: 50)$ was able to increase milk fat level $(7.61 \%)$ of Murrah buffalo and to maintain milk yield more than 5 $\mathrm{kg} /$ day (Seshaiah et al. 2013).

Several sorghum varieties are suitable to be developed in dry land, ideal for food industrial, suitable for bioethanol and have good palatability. Those varieties are Pahat, Samurai 1 and Samurai 2. Those varieties were breeding result by gamma irradiation conducted by National Nuclear Energy Agency (Human 2013). Advantages of Pahat are high seed productivity $(5 \mathrm{t} / \mathrm{ha})$, low tannin $(0.012 \%)$, semi-short rod $(158 \mathrm{~cm})$, and a multifunctional food and feed resources. Advantages of Samurai 1 are high seed productivity (7.5 t/ha), high rod sugar level (12-18\%), and high biomass appropriate for bioethanol substance. Meanwhile, advantages of Samurai 2 are high biomass productivity (47 t/ha), leaf rust diseases (Hemileia vastatrix) and rotten midrib (Sihono et al. 2013). Pahat is a sorghum breed producing Samurai 1 and Samurai 2 varieties.

By-products such as straw and bagasse from those varieties may be used as fibre resources for buffalo diet. Those fibre sources fed in form of silage or fresh. Nutrient value of the third varieties needs to be compared considering that the Samurai 1 and samurai 2 are a derivative of Pahat. Comparation of nutrient value of the silage and fresh fibre resources needs to be conducted to determine nutrient value change occurred due to the breeding process. This study was aimed to compare buffalo diet consisting of $50 \%$ fibre source from sorghum straw Samurai 2 or bagass Samurai 1(as mutants) with diet consisting of $50 \%$ sorghum straw Pahat (as breed).

\section{MATERIALS AND METHODS}

\section{Materials preparation}

Forages used in this study were sorghum straw Pahat, Samurai 1, Samurai 2, silage of sorghum straw Pahat and Samurai 2, bagass Samurai 1, silage of bagass Samurai 1and concentrate. Pahat and Samurai 1 used were the leaves and. Whereras, the bagass Samurai 1 used was squeezed-stems. Pahat and Samurai 2 were harvested in 80 days old. Samurai 1 was harvested in 100 days old as bioethanol raw material. Silage of sorghum straw and bagass were withered and chopped by $\pm 2 \mathrm{~cm}$. the chopped silage was putted in plastic drum silo with capacity $20 \mathrm{~kg}$ and incubated anaerobically for
21 days. Additive was not used during the silage processing. After that, study materials were dried in oven $60^{\circ} \mathrm{C}$, grilled and filtered by $1 \mathrm{~mm}$ filterer.

\section{Experimental design}

This study used Complete Randomize Design with 3 replications with following model:

$$
Y_{i j}=\mu+\alpha_{i}+\varepsilon_{i j}
$$

where:

Yij = the ith treatment observation and jth replication,

$\mathrm{M}=$ general mean,

$\mathrm{Ai}=$ effect of ith treatment,

Eij $=$ random affect of Ith factor and jth replication.

Data obtained will be analyzed using analysis of variance (ANOVA) and followed by Duncan further test (Mattjik \& Sumertajaya 2006) helped by SPSS 16.0.

Buffalo's rumen collection during diferent incubation played as replication. This study used 6 treatments presented in Table 2. Diet was formulated based on nutrient requirement of lactation buffalo $(\mathrm{CP}$ 8\%) (Parakkasi 1999).

\section{Hohenheim gas test (Menke et al. 1979)}

Two hundred $\pm 10 \mathrm{mg}$ of sample was putted into syringe with vaseline smeared-piston. The sample was incubated according to Menke et al. (1979) for 48 hours into $1241.76 \mathrm{ml} \mathrm{Mc}$ Dougall fluid (Krishnamoorthy 2001) and $650 \mathrm{ml}$ rumen fluid. Rumen fluid was obtained from fistulated-buffalo routinely fed by grass and concentrate with ratio by $50: 50$ in DM. Rumen collection was carried out in the morning before fed. The liquor was filtered by 4 layer-gauze. Incubation was conducted in waterbath $39^{\circ} \mathrm{C}$. Thirty $\mathrm{ml}$ media liquor was putted into each syringe. Piston in the syringe was pressed until no empty cavity. Initial volume before sample incubated was recorded. Variables observed were total gas production, $\mathrm{CH} 4$ production, kinetic gas, ammonia $(\mathrm{NH} 3)$, volatile fatty acid (VFA), dry material (DM) degradation, and organic material $(\mathrm{OM})$ degradation.

\section{Measurement of rumen fermentation variables}

Variables observed were total gas production, $\mathrm{CH}_{4}$ production and rumen fermentation products such as $\mathrm{NH}_{3}$, VFA, dry material (DM) degradation, and organic material $(\mathrm{OM})$.

Gas production was recorded on 2, 4, 6, 8, 10, 12, 24 and 48 hour. Gas production reading was quickly conducted to minimize temperature change. This measurement was according to Krishnamoorthy (2001). 
Table 1. Composition of experimental diet based on DM with fibre source and concentrate ratio by $50: 50$

\begin{tabular}{|c|c|c|c|c|c|c|}
\hline \multirow{2}{*}{ Diet Raw Materials } & \multicolumn{6}{|c|}{ Treatment } \\
\hline & $\mathrm{P} 1$ & $\mathrm{P} 2$ & $\mathrm{P} 3$ & $\mathrm{P} 4$ & P5 & P6 \\
\hline Soybean meal & 4.5 & 4.5 & 4.5 & 4.5 & 4.5 & 4.5 \\
\hline Pollard & 5 & 5 & 5 & 5 & 5 & 5 \\
\hline Onggok (cassava waste) & 14.5 & 14.5 & 14.5 & 14.5 & 14.5 & 14.5 \\
\hline Rice bran & 14.25 & 14.25 & 14.25 & 14.25 & 14.25 & 14.25 \\
\hline Soy ketchup pulp & 7.5 & 7.5 & 7.5 & 7.5 & 7.5 & 7.5 \\
\hline Lacta mineral & 1 & 1 & 1 & 1 & 1 & 1 \\
\hline Urea & 0.75 & 0.75 & 0.75 & 0.75 & 0.75 & 0.75 \\
\hline Salt & 0.5 & 0.5 & 0.5 & 0.5 & 0.5 & 0.5 \\
\hline Lime & 0.5 & 0.5 & 0.5 & 0.5 & 0.5 & 0.5 \\
\hline Molases & 1.5 & 1.5 & 1.5 & 1.5 & 1.5 & 1.5 \\
\hline Straw sorghum Pahat & 50 & - & - & - & - & - \\
\hline Straw sorghum silage Pahat & - & 50 & - & - & - & - \\
\hline Straw sorghum Samurai 2 & - & - & 50 & - & - & - \\
\hline Straw sorghum silage Samurai 2 & - & - & - & 50 & - & - \\
\hline Bagass sorghum Samurai 1 & - & - & - & - & 50 & - \\
\hline Bagass sorghum silage Samurai 1 & - & - & - & - & - & 50 \\
\hline
\end{tabular}

Kinetic gas was measured by exponential method of Ørskov \& McDonald (1979) $\mathrm{p}=\mathrm{a}+\mathrm{b}$ (1-e-ct). a and b constants were soluble and insoluble fraction but may be degradable, respectively. The c constant was constantly fraction rate per $t$ unit time. Calculation of a, b, and c used fitcurve Naway® software.

Measurement of $\mathrm{CH}_{4}$ was carried out after determination of $\mathrm{CH}_{4}$ concentration in total gas from fermentation of each syringe. Measurement of $\mathrm{CH}_{4}$ concentration conducted using MRU gas Analyzer®. $\mathrm{CH}_{4}$ concentration measurement was conducted to incubation result of the $48^{\text {th }}$ hour. Readed value on MRU gas Analyzer® was percentation of $\mathrm{CH}_{4}$ stored in the syringe. Variables observed were $\mathrm{CH}_{4}$ concentration and $\mathrm{CH}_{4}$ production of buffalo diet in every $200 \mathrm{mg}$ digested organic matter. $\mathrm{NH}_{3}$ measurement was carried out by Conway microdifusion method in GLP (1966). VFA measurement was carried out by steam destilation method (Warner 1964). DM and OM measurements were carried out according to measurement of Blümmel et al. (1997).

\section{RESULT AND DISCUSSION}

\section{Total gas production}

Measurement result of the total gas production was presented in Table 3. The total gas production between treatments was significantly no different on $2^{\text {nd }}$ and $4^{\text {th }}$ hour incubation. Difference began to show in $6^{\text {th }}$ hour incubation. The highest total gas production was on $8^{\text {th }}$ $12^{\text {th }}$ incubation produced by P6. On the $24^{\text {th }}$ hour incubation, the highest total gas production was produced by $\mathrm{P} 4, \mathrm{P} 6$, and $\mathrm{P} 2(\mathrm{P}<0.05)$. On the $48^{\text {th }}$ hour incubation was produced by $\mathrm{P} 4$ and $\mathrm{P} 2$. Gas production gradualy increased with increasing the incubation time. $\mathrm{CO}_{2}$ and $\mathrm{CH}_{4}$ produced in this method derived from directly and undirectly substrate fermentation through VFA buffering mechanism, that is $\mathrm{CO}_{2}$ which was released from buffer bicarbonate produced during fermentation process (Getachew et al. 1998; Jayanegara et al. 2009).

Gas profile dynamic was related to nutrient content difference in the six diets (Table 2). P1, P3, and P4 treatments had low gas production rate in the early incubation hours due to high crude fibre $(\mathrm{CF})$ content, in the contrary with $\mathrm{P} 2$ and $\mathrm{P} 4$ that produced the highest gas in the early hour incubation due to the lowest $\mathrm{CF}$ content. High fibre in diet might cause decrease on rumen microbial activity on less than 24 hours of diet incubation (Kumar et al. 2007), however gas production rate from fermentation by microbe was higher on 48 hours of incubation. This was caused by rumen microbial started to digest the fiber after 24 hours incubation.

Coefficient of gas production kinetic was calculated by exponential model of Ørskov \& McDonald (1979), where maximum gas production $(\mathrm{a}+\mathrm{b})$ and gas production rate (c) presented in Table 3. The maximum gas production $(\mathrm{a}+\mathrm{b})$ was significantly different 
Sugoro et al. Gas production and rumen fermentation characteristics of buffalo diets containing by-product

Table 2. Composition of experimental diet nutrient basen on DM with fibre source and concentrate ratio by $50: 50$

\begin{tabular}{lrrrrrr}
\hline \hline \multirow{2}{*}{ Nutrient composition (\%) } & \multicolumn{5}{c}{ Treatment } \\
\cline { 2 - 7 } & \multicolumn{1}{c}{ P1 } & \multicolumn{1}{c}{ P2 } & P3 & P4 & P5 & P6 \\
\hline Dry matter & 90.37 & 89.51 & 90.36 & 88.08 & 90.33 & 89.22 \\
Organic matter & 86.75 & 85.34 & 85.32 & 85.34 & 84.33 & 87.48 \\
Crude protein & 9.04 & 12.15 & 11.04 & 11.86 & 8.57 & 8.25 \\
Crude fiber & 26.06 & 22.67 & 24.80 & 26.26 & 23.26 & 19.66 \\
Crude fat & 2.71 & 1.14 & 1.40 & 1.38 & 1.72 & 2.06 \\
Free nitrogen extract & 48.94 & 49.38 & 48.08 & 45.84 & 50.78 & 57.51 \\
\hline
\end{tabular}

Table 3. Production of total gas and kinetic gas in vitro of buffalo diet containing of sorghum during incubation for 2-48 hours (ml/200mg bk)

\begin{tabular}{|c|c|c|c|c|c|c|c|c|c|c|}
\hline \multirow{2}{*}{ Treatment } & \multicolumn{8}{|c|}{ Incubation time (hour) } & \multicolumn{2}{|c|}{ Kinetic gas } \\
\hline & 2 & 4 & 6 & 8 & 10 & 12 & 24 & 48 & $a+b$ & $\mathrm{c}$ \\
\hline P1 & 7.04 & 11.90 & $16.10^{\mathrm{b}}$ & $19.37^{\mathrm{b}}$ & $23.36^{\mathrm{b}}$ & $26.25^{\mathrm{c}}$ & $39.31^{\mathrm{c}}$ & $52.77^{\mathrm{c}}$ & $59.22^{\mathrm{ab}}$ & 0.045 \\
\hline $\mathrm{P} 2$ & 9.38 & 14.97 & $19.69^{\mathrm{a}}$ & $23.27^{\mathrm{ab}}$ & $26.84^{\mathrm{ab}}$ & $30.42^{\mathrm{ab}}$ & $42.96^{\mathrm{ab}}$ & $56.19^{\mathrm{a}}$ & $60.99^{a}$ & 0.050 \\
\hline P3 & 7.50 & 12.14 & $16.54^{\mathrm{ab}}$ & $20.54^{\mathrm{ab}}$ & $23.61^{\mathrm{b}}$ & $27.60^{\mathrm{bc}}$ & $40.05^{c}$ & $52.67^{\mathrm{c}}$ & $57.92^{\mathrm{b}}$ & 0.049 \\
\hline P4 & 7.77 & 13.90 & $18.61^{\mathrm{ab}}$ & $22.38^{\mathrm{ab}}$ & $25.92^{\mathrm{ab}}$ & $30.16^{\mathrm{ab}}$ & $44.29^{\mathrm{a}}$ & $56.31^{\mathrm{a}}$ & $60.86^{\mathrm{a}}$ & 0.053 \\
\hline P5 & 8.27 & 14.05 & $18.74^{\mathrm{ab}}$ & $22.55^{\mathrm{ab}}$ & $26.98^{\mathrm{ab}}$ & $30.18^{\mathrm{ab}}$ & $42.14^{\mathrm{b}}$ & $54.04^{\mathrm{bc}}$ & $57.21^{\mathrm{b}}$ & 0.057 \\
\hline P6 & 7.61 & 14.06 & $19.45^{\mathrm{ab}}$ & $23.93^{\mathrm{a}}$ & $28.02^{\mathrm{a}}$ & $31.70^{\mathrm{a}}$ & $43.64^{\mathrm{ab}}$ & $54.86^{\mathrm{ab}}$ & $56.99^{\mathrm{b}}$ & 0.065 \\
\hline SEM & 0.414 & 0.434 & 0.479 & 0.563 & 0.588 & 0.577 & 0.476 & 0.403 & 0.492 & 0.002 \\
\hline
\end{tabular}

$\mathrm{P} 1=$ Straw sorghum Pahat 50\%:concentrat 50\%

$\mathrm{P} 2=$ Straw sorghum silage Pahat 50\%:concentrat 50\%

$\mathrm{P} 3=$ Straw sorghum Samurai $250 \%$ :concentrat $50 \%$

$\mathrm{P} 4=$ Straw sorghum silage Samurai $250 \%$ :concentrat $50 \%$

P5 = Bagass sorghum Samurai $150 \%$ :concentrat $50 \%$

P6 $=$ Silage bagass sorghum Samurai $150 \%$ :concentrat 50\%

Different superscript in the same column shows significantly difference $(\mathrm{P}<0.05)$;

$\mathrm{a}+\mathrm{b}=$ Maximum gas production;

$\mathrm{c}=$ Gas production rate;

$\mathrm{SEM}=$ Standard Error Mean

$(\mathrm{P}<0.05)$ between treatments. Gas production rate was not significantly different in all treatments. The highest maximum gas production was produced by $\mathrm{P} 2$ and $\mathrm{P} 4$ and has the same trend with CP content of diet (Table 2). $\mathrm{P} 2$ and $\mathrm{P} 4$ consisted of high $\mathrm{CP}$ and tend to produce higher maximum gas production. Different with Luna et al. (2013) who reported that CP content had no correlation with maximum gas production. Protein fermentation would produce aminia affecting buffer bicarbonate balance through ion $\mathrm{H}^{+}$neutralization mechanism without releasing $\mathrm{CO}_{2}$ (Cone \& Van Gelder 1999; Salem et al. 2013). This difference was caused by diet substrate difference in the treatment. Combination of sorghum and concentrate in this study might maximize CP quality of diet for microbial fermentation. Non Protein Nitrogen (NPN) obtained from urea in the concentrate was able to be optimized for microbial protein synthesis. Optimal microbial performance affected increase of maximum gas production.

\section{$\mathrm{CH}_{4}$ production}

Total gas production increasing was followed by $\mathrm{CH}_{4}$ production. Higher total gas production caused high $\mathrm{CH}_{4}$ production. $\mathrm{CH}_{4}$ variable was used to measure $\mathrm{CH}_{4}$ emition decrease level. $\mathrm{CH}_{4}$ concentration of buffalo diet from 48 hour incubation and $\mathrm{CH}_{4}$ production in every $100 \mathrm{mg}$ organic material were presented in Figure 1. The lowest $\mathrm{CH}_{4}$ concentration was produced by $\mathrm{P} 4$ and had no significant difference with $\mathrm{P} 1$ and $\mathrm{P} 2$. The lowest $\mathrm{CH} 4$ production per unit digested $\mathrm{OM}$ was produced by $\mathrm{P} 1$ and had no significant difference with $\mathrm{P} 4, \mathrm{P} 2$, and P3. The highest $\mathrm{CH}_{4}$ concentration was produced by $\mathrm{P} 5$ with higher concentration by $66.60 \%$ $(\mathrm{P}<0.05)$ compared with $\mathrm{P} 1 . \mathrm{CH}_{4}$ concentration in $\mathrm{P} 6$ was also higher by $61.49 \%(\mathrm{P}<0.05)$ than $\mathrm{P} 1$.

High $\mathrm{CH}_{4}$ concentration and production per unit OM digested in P5 and P6 were affected by low CP content. Widiawati et al. (2010) reported that higher 

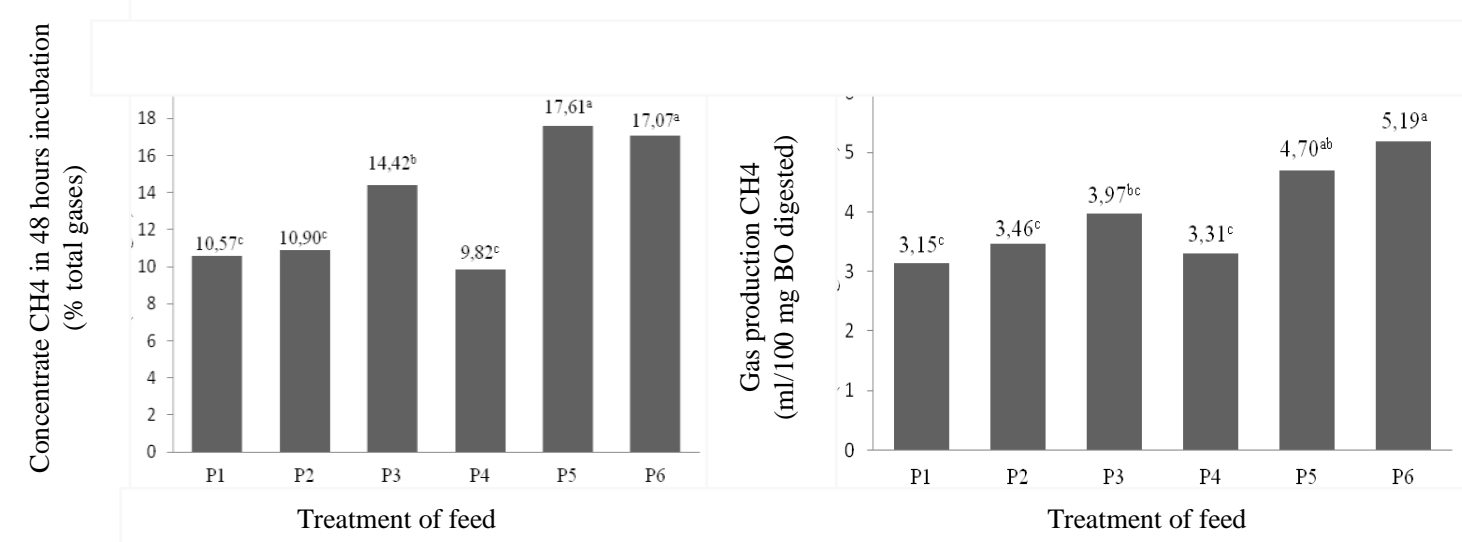

$\mathrm{P} 1=$ Straw sorghum Pahat 50\%:concentrat 50\%

$\mathrm{P} 2=$ Straw sorghum silage Pahat 50\%:concentrat 50\%

P3 = Straw sorghum Samurai $250 \%$ :concentrat 50\%

P4 = Straw sorghum silage Samurai $250 \%$ :concentrat $50 \%$

P5 = Bagass sorghum Samurai $150 \%$ :concentrat 50\%

P6 = Silage bagass sorghum Samurai $150 \%$ :concentrat $50 \%$

Different superscript in the same column shows significantly difference $(\mathrm{P}<0.05)$

Figure 1. Concentration of $\mathrm{CH} 4$ of buffalo diet from 48 hour incubation (left) and $\mathrm{CH} 4$ production of the diet in every $100 \mathrm{mg}$ organic matter digested (right)

content and good quality of $\mathrm{CP}$ might produce lower $\mathrm{CH}_{4}$. Protein degradation would produce $\mathrm{NH} 4$ combined with $\mathrm{CO}_{2}$ to produce lower $\mathrm{CH}_{4}$ (Getachew et al. 1998). Negative effect of fermentative digestion in the rumen was a lot of $\mathrm{CH}_{4}$ wasted. Energy losses in feed become $\mathrm{CH}_{4}$ reached $7 \%$ in ruminant (Kamal 1994). Baker (1999) reported that $\mathrm{CH}_{4}$ production indicated a lot of energy losses in form of gas showing low feed efficiency. Low $\mathrm{CH}_{4}$ concentration in $\mathrm{P} 1, \mathrm{P} 2$, and $\mathrm{P} 4$ showed the third diets were able to increase efficiency of rumen fermentation.

High $\mathrm{CH}_{4}$ concentration in P5 and P6 might also be caused by fibre resources used was bagass sorghum harvested in 100 days old. P1, P2, P3, and P4 used sorghum fibre source harvested in 80 days old, so that $\mathrm{CH}_{4}$ concentration produced was lower. Difference of harvest age affected dissolved and structured carbohydrate content. The dissolved carbohydrate would decrease, whereas structured carbohydrate would increase as well as crop age. Structured carbohydrate would be more difficult to be degraded than dissolved carbohydrate (Van Soest 1994). Widiawati et al. (2010) reported that high cellwall fraction produced high portion of acetat acid and $\mathrm{CH}_{4}$. In Shahbazi (2008), it was reported that cellwall fraction was slowly fermented due to cellulose which was acociated in the lignin matrix. Besides, silage treatment caused the structured carbohydrate getting less due to degradation process carried out by microba during incubation (Yahaya et al. 2002).
It was suspected that there were cellwall fraction in the fibre source in the P5 and P6. It could be seen in low maximum gas production $(a+b$ coefficient $)$ in the P5 and P6 (Table 3). High cellwall fraction produced high $\mathrm{CH}_{4}$. Utilization of sorghum fibre resource Pahat and Samurai 2 in P1, P2, P3, and P4 harvested in 80 days old had low concentration $\mathrm{CH}_{4}$ and $\mathrm{CH}_{4}$ production per unit $\mathrm{OM}$ digested compared to the P5 and P6. P2 and P4 diet, which was silage, was able to decrease $\mathrm{CH}_{4}$ and $\mathrm{CH}_{4}$ production per unit digested OM, but not in P6 (bagass silage). This was suspected occurred because bagass consisted of higher structured carbohydrate due to the squeeze processing. Decrease of $\mathrm{CH}_{4}$ production might decrease wasted feed energy losses, so that increasing efficiency of feed utilization (Widiawati et al. 2010).

\section{Characteristic of rumen fermentation}

Characteristics of rumen fermentation observed were $\mathrm{NH}_{3}$, VFA, DMD, and OMD produced after 48 hour incubation (Table 4). $\mathrm{NH}_{3}$ was not significantly different between treatments. VFA, DMD, and OMD showed significant different $(\mathrm{P}<0.05)$ between treatments. P4 showed highest in those fourth variables. $\mathrm{NH}_{3}$ concentration between treatments showed no significant different, even though $\mathrm{P} 4$ tended to produce high $\mathrm{NH}_{3}$ concentration $(39.74 \mathrm{mg} / 100 \mathrm{ml})$. Not significant different between treatments was caused by percentage of NPN (urea) resources use in identic diet 
Sugoro et al. Gas production and rumen fermentation characteristics of buffalo diets containing by-product

Table 4. Characteristic of rumen fermentation In Vitro of buffalo diet based on sorghum in 48 hour incubation

\begin{tabular}{lccccccc}
\hline \hline \multirow{2}{*}{ Variable } & \multicolumn{7}{c}{ Treatment } \\
\cline { 2 - 8 } & P1 & P2 & P3 & P4 & P5 & P6 & SEM \\
\hline NH3 (mg/100ml) & 36.79 & 34.94 & 33.85 & 39.74 & 34.23 & 33.97 & 0.942 \\
VFA total (mM) & $91.32^{\mathrm{b}}$ & $86.38^{\mathrm{b}}$ & $91.32^{\mathrm{b}}$ & $109.83^{\mathrm{a}}$ & $92.55^{\mathrm{b}}$ & $92.55^{\mathrm{b}}$ & 2.321 \\
DMD (\%) & $57.57^{\mathrm{ab}}$ & $60.59^{\mathrm{ab}}$ & $55.90^{\mathrm{b}}$ & $62.93^{\mathrm{a}}$ & $54.73^{\mathrm{b}}$ & $58.59^{\mathrm{ab}}$ & 0.912 \\
OMD (\%) & $56.44^{\mathrm{ab}}$ & $56.42^{\mathrm{ab}}$ & $52.44^{\mathrm{bc}}$ & $59.97^{\mathrm{a}}$ & $49.31^{\mathrm{c}}$ & $55.57^{\mathrm{abc}}$ & 1.073 \\
\hline
\end{tabular}

$\mathrm{P} 1=$ Straw sorghum Pahat 50\%:concentrat 50\%)

$\mathrm{P} 2=$ Straw sorghum silage Pahat 50\%:concentrat $50 \%$ )

$\mathrm{P} 3=$ Straw sorghum Samurai $250 \%$ :concentrat $50 \%$ )

P4 = Straw sorghum silage Samurai 2 50\%:concentrat 50\%)

P5 = Bagass sorghum Samurai $150 \%$ :concentrat $50 \%$ )

P6 = Silage bagass sorghum Samurai $150 \%$ :concentrat 50\%)

Different superscript in the same column shows significantly difference $(\mathrm{P}<0.05)$; $\mathrm{SEM}=$ standard error mean

(Table 1). Kang \& Wanapat (2013) reported that buffalo rumen microbial had high efficiency in NPN use to synthesize microbial protein compared to another feed stuff. Amount of protein of diet was a factor affecting $\mathrm{NH}_{3}$ production (McDonald et al. 2002). Different result in this study showed CP content of diet had no affect $\mathrm{NH}_{3}$ concentration. This was suspected due to variated degradation level from different protein concentration feed resources.

NH3 showed high concentration around 33.85-39.74 $\mathrm{mg} / 100 \mathrm{ml}$ in all treatments. Concentrate content in treatment affected high ammonia production due to increase of sample protein content. This result was different with optimal concentration $(5 \mathrm{mg} / 100 \mathrm{ml})$ for microbial fermentation in closed culture system and depended on feed fermentability level (Wanapat \& Rowlison 2007; Wanapat et al. 2013). Optimal $\mathrm{NH}_{3}$ concentration in the rumen of swamp buffalo was 14 mg/100 ml (Wanapat \& Pimpa 1999).

The highest total VFA concentration was produced by $\mathrm{P} 4$ compared to another five treatments $(\mathrm{P}<0.05)$. Leng and Leonard who were cited by Pamungkas et al. (2006) reported that fermentation rate was correlated with VFA concentration, so that VFA concentration change was a reflection of increase of rumen microbial population. One of factors affecting high production of total VFA in $\mathrm{P} 4$ was high concentration of $\mathrm{NH}_{3}$. This was an indicator of increase of microbial protein synthesis to increase rumen microbial population. Gas production rate (c), which tended to high in Table 3, also reflected a high VFA concentration as final product. The P4, P5, and P6 produced high total VFA as well as gas production rate.

Total VFA concentration in rumen-fistulated swamp buffalo fed by sorghum as single diet was $53.5 \mathrm{mM}$. Buffalo rumen fed by fermented rice straw and concentrate produced total VFA concentration by 44.8 , 48.9, and $55.9 \mathrm{mM}$, respectively (Chanthakhoun \& Wanapat 2012). Su-jiang et al. (2016) reported that total VFA from in vitro incubation in sweet sorghum silage and sorghum silage was 35.0 and $27.54 \mathrm{mM}$, respectively. Result in this study showed total VFA concentration around 86.38-109.83 mM, respectively. This higher result was caused by feed substrate difference. Fibre source from sorghum was more optimal to support rumen microbial performance if it was combined with concentrate in the diet.

The highest DMD and OMD was produced by $\mathrm{P} 4$, but were no significantly different than P1, P2, and P6. $\mathrm{P} 4$ produced higher DMD and OMD than $\mathrm{P} 3$ and $\mathrm{P} 5$ $(\mathrm{P}<0.05)$. Diet with silage as fibre source $(\mathrm{P} 2, \mathrm{P} 4$, and P6) tended to produce higher OMD than P1, P3, and P5. This respon was caused by structured carbohydrate content in the fibre source have been fermented by microb in the silage process. This caused faster degradation of DM. Silage treatment might increase degradation value of $\mathrm{OM}$ due to microflora activity during fermentation. The activity was effect of cellulase extra-curricular enzyme cutting cellulose bind in the silage substance (Jancik et al. 2011). OMD value, numericaly, was proportional to $\mathrm{NH}_{3}$ concentration (Table 4) and maximum gas production value $(a+b)$ (Table 3). High maximum gas production reflected organic material degradation level in diet. This proved that optimal fermentation level during 48 hour incubation was produced by $\mathrm{P} 1, \mathrm{P} 2$, and P4. From the production of total VFA, DMD, OMD, and low production of $\mathrm{CH}_{4}, \mathrm{P} 4$ was better than other treatments. Sorghum silage Samurai 2 might be used to substitute fibre source from sorghum straw and sorghum bagass.

\section{CONCLUSION}

Samurai 2 was better than Pahat and Samurai 1 for buffalo diet. This was presented by high production of gas, total VFA, and Dry Matter Degradation. Diet containing of Samurai 2 also produced low $\mathrm{CH}_{4}$ in vitro. It needed further in vitro test to strengthen evaluation study of this buffalo diet. 


\section{ACKNOWLEDGEMENT}

The author thanks to Ir. Suharyono, M.Rur.Sci, Mr. Eddy Irawan Kosasih, Mr. Adul, Mr. Dedi Ansori, and Mr. Udin Sinam for helps and support during this study. This study was funded by PAIR BATAN.

\section{REFERENCES}

Baker SK. 1999. Rumen methanogenes and inhibition of methanogenesis. Aust J Agric Res. 50:1293-1298.

Blümmel M, Makkar HPS, Becker K. 1997. In vitro gas production: A technique revisited. J Anim Phys Nutr. 77:24-34.

Chanthakhoun V, Wanapat M. 2012. The in vitro gas production and ruminal fermentation of various feeds using rumen fluid from swamp buffalo and cattle. Asian J Anim Vet Adv. 7:54-60.

Colombo D, Crovetto GM, Colombini S, Galassi G, Rapetti L. 2007. Nutritive value of different hybrids of sorghum forage determined in vitro. Ital J Anim Sci. 6:289-291.

Cone JW, Van Gelder AH. 1999. Influence of protein fermentation on gas production profiles. Anim Feed Sci Tech. 76:251-264.

[GLP] General Laboratory Procedure. 1966. Department of dairy sciences. Madison (USA): University of Wisconsin.

Getachew G, Blümmel M, Makkar HPS, Becker K. 1998. In vitro gas measuring techniques for assessment of nutritional quality of feeds: a review. Anim Feed Sci Tech. 72:261-281.

Human S. 2013. Pemuliaan sorgum dengan iptek nuklir [accessed October 24th 2013]. http://www.batan.go.id/ patir/2012/p_03/01_org/pert/pemuliaan/AIN\%20Sorgu m.pdf

Jančik F, Koukolova V, Homolka P, Haman J. 2011. Comparison of analyses to predict ruminal fibre degradability and indigestible fibre in temperate grass silages. S Afr J Anim Sci. 41:297-308.

Jančik F, Koukolova V, Homolka P. 2010. Ruminal degradability of dry matter and neutral detergent fibre of grasses. Czech J Anim Sci. 55:359-371.

Jayanegara A, Makkar HPS, Becker K. 2009. Emisi metana dan fermentasi rumen in vitro ransum hay yang mengandung tanin murni pada konsentrasi rendah. Media Peternakan. 32:184-194.

Kamal M. 1994. Nutrisi ternak 1. Yogyakarta (Indones): Universitas Gadjah Mada.

Kang S, Wanapat M. 2013. Increasing rumen microbial protein synthesis using cassava chip and urea in swamp buffaloes. Proceedings of the 10th World Buffalo Congress. Phuket (Thailand).
Krishnamoorthy U. 2001. RCA training workshop on in vitro techniques for feed evaluation. Jakarta (Indones): The International Atomic Energy Agency. p. 17.

Kumar R, Kamra DN, Agarwal N, Chaudhary LC. 2007. In vitro methanogenesis and fermentation of feeds containing oil seed cakes with rumen fluid of buffalo. Asian-Aust J Anim Sci. 20:1196-1200.

Luna AC, Diaz DD, Murphy MR, Almeida FAR, Villalobos G, Gutierrez JAO. 2013. Relationships between chemical composition, in vitro dry matter, neutral detergent fiber digestibility and in vitro gas production of corn and sorghum silages. J Anim Vet Adv. 12:15241529 .

Mattjik AA, Sumertajaya M. 2006. Perancangan percobaan dan aplikasi SAS dan minitab. Jilid I. Edisi ke 2. Bogor (Indones): IPB Press.

McDonald P, Edward RA, Greenhalgh JFD, Morgan CA. 2002. Animal nutrition. 6th ed. New York (USA): Scientific and Tech John Willey \& Sons. Inc

Menke KH, Raab L, Salewski A, Steingass H, Fritz D, Schneider W. 1979. The estimation of the digestibility and metabolizable energy content of ruminant feeding stuffs from the gas production when they are incubated with rumen fluid in vitro. J Agr Sci. 93:217-222.

Ørskov ER, Mcdonald I. 1979. The estimation of protein degradability in the rumen from incubation measurements weighted according to the rate of passage, J Agr Sci Camb. 92:499-503.

Pamungkas D, Sevilla CC, Lustria UM. 2006. Changes in rumen ecosystem and feed dry matter degradability of buffalo which received rumen content of cattle through cross inoculation. JITV. 11:24-33.

Parakkasi A. 1999. Ilmu nutrisi dan makanan ternak ruminansia. Jakarta (Indones): Universitas Indonesia.

Salem AZM, Chuan-She Z, Zhi-liang T, Mellado M, Salazar MC, Elghandopur MMMY, Edongo NE. 2013. In vitro Ruminal Gas Production Kinetics of Four Fodder Trees Ensiled With or Without Molasses and Urea. J Integr Agr. 12:1234-1242.

Seshaiah CV, Rao SJ, Reddy YR, Mahendar M, Kumar MK. 2013. Effect of feeding differently processed sweet sorghum bagasse based complete rations on feeding behaviour, milk production and cost economics in graded murrah buffaloes. Buffalo Bull. 32:231-238.

Shahbazi HR, Sadeghi AA, Shawrang P, Raisali G. 2008. Effects of gamma irradiation on ruminal DM and NDF degradation kinetics of alfalfa hay, Pak J Biol Sci. 11:1165-1168.

Sihono, Human S, Indriatama WM, Puspitasari W, Parno, Carkum. 2013. Galur Mutan Sorgum PATIR-1 Berdaya Hasil Biji, Biomasa dan Gula Batang Tinggi serta Galur PATIR-4 Hasil Biji Tinggi Kualitas Baik. Perbaikan Proposal Pelepasan Varietas. Pusat Aplikasi Isotop dan Radiasi. BATAN. 
Sirappa MP. 2003. Prospek Pengembangan Sorgum di Indonesia sebagai komoditas alternatif untuk pangan, pakan dan industri. J Litbang Pertanian. 22:133-140.

Su-jiang Z, Chaudhry AS, Ramdani D, Osman A, Xue-feng G, Edwards GR, Cheng L. 2016. Chemical composition and in vitro fermentation characteristics of high sugar forage sorghum as an alternative to forage maize for silage making in Tarim Basin, China. J Integr Agr. $15: 175-182$

Van Soest PJ. 1994. Nutritional ecology of the ruminant. 2nd ed. New York (USA): Comstock Publishing Associates, Cornell University Press, Ithaca.

Wanapat M, Kang S, Phesatcha K. 2013. Enhancing buffalo production efficiency through rumen manipulation and nutrition. Buffalo Bull. 32:258-275.

Wanapat M, Pimpa O. 1999. Effect of ruminal NH3-N levels on ruminal fermentaion, purine derivatives, digestibility and rice straw intake in swamp buffaloes. Asian-Aust J Anim Sci. 12:904-907.
Wanapat M, Rowlinson P. 2007. Nutrition and feeding of swamp buffalo: Feed resources and rumen approach. Ital J Anim Sci. 6:67-73.

Warner AC. 1964. Production of volatile fatty acids in the rumen: Methods of measurement. Nutr Abstr Rev. 34:339-352.

Widiawati Y, Winugroho M, Mahyuddin P. 2010. Estimasi produksi gas metana dari rumput dan tanaman leguminosa yang diukur secara in vitro. Prasetyo $\mathrm{LH}$, Natalia L, Iskandar S, Puastuti W, Herawati T, Nurhayati, Anggraeni A, Damayanti R, Darmayanti NLPI, Estuningsih SE, editors. Prosiding Seminar Nasional Teknologi Peternakan dan Veteriner. Bogor (Indones): Pusat Penelitian dan Pengembangan Peternakan. p. 131-136.

Yahaya MS, Kawai M, Takahashi J, Matsuoka S. 2002. The effects of different moisture content and ensiling time on silo degradation of structural carbohydrate of orchad grass. Asian-Aust J Anim Sci. 11:213-217. 